ARTICLE

\title{
Effect of Maternal Alcohol Consumption on Epididymal Growth in Neonatal Mice
}

${ }^{* 1}$ ONU, J. E., ${ }^{2}$ EZEASOR, D. N. and ${ }^{2}$ IHEMELANDU, E. C.

'Dept. of Veterinary Anatomy, Faculty of Veterinary Medicine, Usmanu Danfodiyo University, P. M. B 2346, Sokoto. ${ }^{2}$ Dept. of Veterinary

Anatomy, Faculty of Veterinary Medicine, University of Nigeria, Nsukka. *Corresponding author: 08035073118. josephatedoga@yahoo.co.uk

\begin{abstract}
SUMMARY
A study was conducted to determine the effect of maternal alcohol consumption on the growth of epididymis in neonatal mice. Three groups of adult female mice were used. The pups of group 1 served as control while the pups of groups 2 and 3 were given $30 \%$ ethanol $(\mathrm{v} / \mathrm{v})$ during pregnancy and during pregnancy and lactation respectively. At $3,4,5$ and 6 weeks of age, 10 male pups were randomly selected from each of the three groups and sacrificed. After sacrifice, the epididymis were dissected out and their weights determined. The results of the study showed significant decrease in the weights and growth rates of the epididymis of the pups exposed to alcohol when compared with the controls. The study has therefore demonstrated that maternal alcohol intake during pregnancy and during pregnancy and lactation affects the growth of epididymis of the neonates and that the epididymis of the neonates exposed to alcohol attempted catch-up growth with the controls
\end{abstract}

KEY WORDS: Maternal alcohol consumption, Epididymis, Growth, Neonatal mice.

\section{INTRODUCTION}

It has been established that alcohol has a potential teratogenic effects (Jones and Smith, 1973). Morrison and Maykut, (1979) described a pattern of congenital abnormalities in children born to women with severe alcoholism. These reports emphasized retardation of weight and length of such infants at birth and noted the lack of catch-up growth in them. Human and nonhuman primate studies on brain structure and function now strongly suggest that consumption of alcohol during pregnancy can affect fetal brain structure and function (Clarren et al., 1985). As a result of this effect, the hypothalamic-pituitary-gonadal axis regulation which plays a critical role in control of reproduction (Grober et al., 1998) could be disrupted. The hormone from this axis plays a critical role in stimulating the growth and activity of the reproductive system (Fugii, 1976).

The effects of maternal alcohol intake on the growth and development of some parts of the body in both human and experimental animals have been reported (Lee and Leichter, 1980; Ihemelandu, 1984; Clarren et al., 1985; Piqueras-Renau et al., 1987; Nwaogu and Ihemelandu, 1999a, b). In the reproductive system, reduced growth have been reported on the testes (Onu and Ezeasor, 2001; Onu et al., 2002a, b; Fakoya and Caxton-Martins, 2004) and on the penis (Onu et al., 2004). The possible effect of alcohol intake during pregnancy and during pregnancy and lactation on the growth of epididymis has not been elucidated, hence this study.

\section{Materials and methods}

The experimental procedures employed in this study were similar to those of Lee and Leichter (1980). Thirty six (36) virgin female and 9 immature male mice used in this study were randomly selected at the weaning age of 21 days from a colony of locally in-bred mice. The mice were maintained for research in the animal house of the Faculty of Veterinary Medicine, University of Nigeria, Nsukka. The virgin female mice were divided into three groups of 12 each while the immature males were kept separately. The mice were housed separately in cages with screened tops and were acclimatized for three weeks before the beginning of the study. All the female mice in the three groups and the males were provided water and commercial diet (Guinea Feed produced by Bendel Feed and Flour Mills, Nigeria, PLC, Ewu, Delta State) ad 
libitum until they were six weeks of age. At the beginning of the $7^{\text {th }}$ week of age, the female mice in group 2 and 3 were given $10 \%$ ethanol $(\mathrm{v} / \mathrm{v})$ in drinking water for 2 weeks and $20 \%$ ethanol $(\mathrm{v} / \mathrm{v})$ for another 1 week. The female mice in the three groups were then bred overnight by introducing 1 male mouse into a cage housing 4 female mice. Day 1 of pregnancy was presumed after observation of vaginal plug the following morning. Following diagnosis of pregnancy, the female mice in groups 2 and 3 were given 30\% ethanol ( $\mathrm{v} / \mathrm{v})$ till delivery. After delivery, the alcohol for group 2 (alcohol exposure during pregnancy) was replaced with drinking water while group 3 (alcohol exposure during pregnancy and lactation) continued to receive the $30 \%$ ethanol $(\mathrm{v} / \mathrm{v})$ in drinking water until their pups were weaned at 21 days of age. At the age of 3, 4, 5 and 6 weeks, 10 male pups were randomly selected from groups 1,2 and 3 and sacrificed. A total of 120 pups were used in the study.

\section{Quantitative measurements}

After the sacrifice, the two epididymis were dissected out, trimmed of extraneous tissue and weighed using Metler's Analytical Balance (BFN390). After this, the relative growth rates of the organ were calculated thus: the mean of logarithms of the weights at week 3 was calculated and then used to divide the logarithms of their respective weights at week 4, 5 and 6 (Nwaogu and Ihemelandu, 1999a).

\section{Statistical analysis}

Means and standard errors were calculated for each group. One-way analysis of variance (ANOVA) was used to examine whether there were significant differences in the parameters measured amongst the pups of the three groups. Following the observation that there were significant differences amongst the three groups, Duncan's Multiple Range Test (DMRT) (Duncan, 1955) was used to determine which groups differed. For the statistical test, $\mathrm{p}<0.05$ and $\mathrm{p}<0.01$ were considered statistically significant.

\section{RESULTS Epididymal Weights}

Comparison of the epididymal weights between the control and the two alcohol-exposed groups using ANOVA showed that there was significant difference $(\mathrm{p}<0.01)$ amongst the three groups throughout the duration of the study (Table I). Further analysis using DMRT showed that the epididymis of control mice weighed significantly greater than those from mice exposed to alcohol during pregnancy at week 3,4 and $5(\mathrm{p}<0.01)$ and at week $6(\mathrm{p}<0.05)$. Similarly, the epididymis of the control mice weighed significantly greater $(\mathrm{p}<0.01)$ than those of the mice exposed to alcohol during pregnancy and lactation throughout the duration of the study. Comparison of the epididymis of the two alcohol-exposed groups showed that the weights were similar $(\mathrm{p}>0.05)$ at week 3 and 4 . However, the epididymis of mice exposed to alcohol during pregnancy only weighed significantly greater $(\mathrm{p}<0.01)$ than those from the mice that were exposed to alcohol during pregnancy and lactation at week 5 and 6

\section{Epididymal growth rates}

There was significant difference $(\mathrm{p}<0.01)$ amongst the three groups throughout the period of study (Table II). The results of Duncan's analysis showed that the epididymis of the two alcohol-exposed groups had significantly higher $(\mathrm{p}<0.01)$ growth rates when compared with the control while the growth rates of the epididymis of the two alcohol-exposed groups were similar ( $p>0.05)$ throughout the duration of the study.

Table I: Comparison of epididymal weights $(\mathrm{mg})$ of control mice and mice exposed to alcohol during pregnancy and during pregnancy and lactation

\begin{tabular}{|c|l|c|c|}
\hline $\begin{array}{l}\text { Age (weeks) } \\
\text { at sacrifice }\end{array}$ & $\begin{array}{l}\text { Control } \\
(n=10)\end{array}$ & $\begin{array}{l}\text { Prenatal alcohol- } \\
\text { exposed }(n=10)\end{array}$ & $\begin{array}{l}\text { Pre-and post- } \\
\text { natal alcohol- } \\
\text { exposed }(n=10)\end{array}$ \\
\hline 3 & $15.65 \pm 1.30^{\mathrm{a}}$ & $6.23 \pm 0.40^{\mathrm{b}}$ & $4.77 \pm 0.40^{\mathrm{b}}$ \\
4 & $22.35 \pm 1.00^{\mathrm{a}}$ & $12.14 \pm 1.20^{\mathrm{b}}$ & $9.53 \pm 1.00^{\mathrm{b}}$ \\
5 & $33.26 \pm 1.60^{\mathrm{a}}$ & $18.06 \pm 1.00^{\mathrm{b}}$ & $10.31 \pm 1.40^{\mathrm{c}}$ \\
6 & $38.09 \pm 1.00^{\mathrm{a}}$ & $37.05 \pm 1.00^{\mathrm{b}}$ & $18.19 \pm 1.40^{\mathrm{c}}$ \\
\hline
\end{tabular}

Values represent means \pm SEM for each measurement Means with different superscript on the same row are significantly different at $p<0.05$

Table Il: Comparison of epididymal growth rates of control mice and mice exposed to alcohol during pregnancy and during pregnancy and lactation

\begin{tabular}{|c|l|l|l|}
\hline $\begin{array}{l}\text { Age (weeks) } \\
\text { at sacrifice }\end{array}$ & $\begin{array}{l}\text { Control } \\
(n=10)\end{array}$ & $\begin{array}{l}\text { Prenatal alcohol- } \\
\text { exposed }(n=10)\end{array}$ & $\begin{array}{l}\text { Pre-and post- } \\
\text { natal alcohol- } \\
\text { exposed }(n=10)\end{array}$ \\
\hline 4 & $1.14 \pm 0.01^{\mathrm{a}}$ & $1.35 \pm 0.03^{\mathrm{b}}$ & $1.47 \pm 0.40^{\mathrm{b}}$ \\
5 & $1.29 \pm 0.02^{\mathrm{a}}$ & $1.59 \pm 0.02^{\mathrm{b}}$ & $1.53 \pm 0.03^{\mathrm{b}}$ \\
6 & $1.34 \pm 0.01^{\mathrm{a}}$ & $1.98 \pm 0.02^{\mathrm{b}}$ & $1.89 \pm 0.10^{\mathrm{b}}$ \\
\hline
\end{tabular}

Values represent means \pm SEM for each measurement Means with different superscript on the same row are significantly different at $p<0.05$ 


\section{DISCUSSION}

This study has demonstrated that maternal alcohol intake in mice during pregnancy and during pregnancy and lactation retarded the growth of the epididymis. This is evident when absolute epididymal weights were used as growth indices. When the two alcohol-exposed groups were compared, it was observed that at 3 and 4 weeks of age, the two groups were similar while those exposed to alcohol during pregnancy alone were bigger than those exposed to alcohol during pregnancy and lactation at 5 and 6 weeks of age. The similarity at 3 weeks of age could be attributable to the effect of alcohol on the two groups while the similarity at 4 weeks of age could be as a result of continued effect of alcohol on those exposed during pregnancy after withdrawal at 3 weeks of age (Zetterman and Sorrel, 1981). The superiority of the epididymal weight of the control over the two alcoholexposed groups at 5 and 6 weeks of age resulted from the effect of the alcohol on the epididymal gowth. This observation is similar to the findings of Taylor et al. (1981) and Onu et al. (2002a) on testicular growth in fetal alcohol syndrome in rat. The observation also agrees with what was described as lack of catch-up growth in fetal alcohol syndrome in humans (Hanson et al., 1976) and in experimental animals (Lee and Leichter, 1980; Ihemelandu, 1984). However, the results of this study also revealed that the epididymis exposed to alcohol during pregnancy and during pregnancy and lactation attempted to catch-up growth with their control counterparts. This is shown by the superiority of the growth rates of the alcohol-exposed groups over the control. This is an indication of an attempt by the alcohol-exposed groups to catchup growth with the control. This observation suggests that the intake of alcohol during pregnancy and during pregnancy and lactation did not suppress completely the attempt by the epididymis to catch-up growth with the controls. This is similar to the observation of Nwaogu and Ihemelandu (1999a, b) on muscle and visceral organs of rat respectively.

The superiority of the epididymal weight exposed to alcohol during pregnancy only over those exposed to alcohol during pregnancy and lactation showed that alcohol ingestion during pregnancy and lactation produced adverse cumulative effect on the growth of epididymis.
This observation is similar to that of Nwaogu and Ihemelandu (1999a, b) on muscle and visceral organs of rats respectively and Onu et al., (2000) on testes and accessory sex organs of mice.

The mechanism by which alcohol intake during pregnancy and during pregnancy and lactation retarded the growth of epididymis was not determined in this study. However, Lee and Leichter, (1980) observed that alcohol consumed during pregnancy adversely affects the regulatory mechanism of growth of the pups and the effects persists after birth. It is well established that severe structural damage occurs to the brains of infant exposed to alcohol during pregnancy (Clarren and Smith, 1978). Taylor (1984) also observed that alcohol impairs fetal hormonal system. Alcohol affects the activity of the endocrine system, both the hormonesecreting glands and the activity of the hormones themselves. Since the endocrine mechanism in the fetuses is similar to that of the adults (Nathanielsz, 1976), the alcohol consumed during pregnancy and during pregnancy and lactation could have disrupted the neuroendocrine functions of the fetuses by its action on hypothalamus sequel to destruction of brain structure and function (Clarren et al., 1985). This action on the hypothalamus could lead to disruption of the hypothalamic-pituitarygonadal axis as suggested by Onu and Ezeasor, (2001) which plays significant role in reproduction (Grober et al., 1998). The hormone from this axis plays a critical role in the growth and activity of the reproductive system (Fugii, 1976).

\section{REFERENCES}

CLARREN, S.K., BOWDEN, and ASTHLY, S. (1985): The brain in fetal alcohol syndrome. Hlth. Res. World. 10: $20-23$.

CLARREN, S.K. and SMITH, D.W. (1978): The fetal alcohol syndrome. New Engl. J. Med. 298: 10631069.

DUNCAN, D.B. (1955): Multiple Range and Multiple Fishers Test. Biometrics II.

FAKOYA, F.A. and CAXTON-MARTINS, E.A. (2004): Morphological alterations in the seminiferous tubules of adult Wistar rats: the effects of prenatal ethanol exposure. Folia Mor-phologica.63(2): 195-202.

FUGII, T. (1976): Role of age and androgen in the regulation of sex accessory organs. Adv. Sex Hormone Res. 3: 103-137.

GROBER, M.S., WINTERSTEIN,G.M., GHAZANFAR, A.A. and EROSCHENKO, V.P. (1998): The effect of 


\section{Nigerian Veterinary Journal 2010 3I(4)}

oestradiol on gonadotropin-rreleasing hormone neurones in the developing mouse brain. Gen. Comp. Endocrinol. 112: 356-363.

HANSON, J.W., JONES, K.L. and SMITH, D.W. (1976): Fetal alcohol syndrome. Experience with 41 patients. J. Amer. Med. Assoc. 235: 1458-1460.

IHEMELANDU, E.C. (1984): Effect of maternal alcohol consumption on pre-and postnatal muscle development. Growth. 48: 35-43.

JONES, K. L. and SMITH, D.W. (1973): Recognition of fetal alcohol syndrome I early infancy. Lancet (I): 999-1001.

LEE, M. and LEICHTER, J. (1980): Effect of litter size on physical growth and maturation of the offspring of rat given alcohol during gestation. Growth. 44: 327-355.

MORRISON, A.B. and MAYKUT, M.O. (1979): Potential adverse effect of maternal alcohol ingestion on the developing fetus and their sequelae in infant and child. Canadian Med. Assc. J. 120:826-828.

NATHANIELSZ, P. (1976): Fetal Endocrinology. An Experimental Approach. Monographs in Fetal Physiology. Amsterdam. North Holland Publishing Company.

NWAOGU, I.C. and IHEMELANDU, E.C. (1999a): Effects of maternal alcohol consumption on the allometric growth of muscles in fetal and neonatal rats. Cells Tissues and Organs. 164: 167-172.

NWAOGU, I. C. and IHEMELANDU, E.C. (1999b): Allometric growth of visceral organs in fetal alcohol syndrome in rats. Nig. Vet. J. 20: 39-40.

ONU, J.E., EZEASOR, D.N. and IHEMELANDU, E.C. (2000): Effects of maternal alcohol consumption on the growth of the testes and accessory sex organs in neonatal mice. J. Life. Environ. Sci. 2(3): 192-102.

ONU, J.E and EZEASOR, D.N. (2001): Retardation of testicular growth in mice in fetal alcohol syndrome: suspected evidence of disruption of hypothalamicpituitary-gonadal axix regulation. Nig. Vet. J. 22(2): 35-41

ONU, J.E., IHEMELANDU, E.C. and EZEASOR, D.N. (2002a): Testicular growth in fetal a $1 \mathrm{c} \mathrm{o} \mathrm{h} \mathrm{o} 1$ syndrome of mice. Sahel Med. J. 5: 47-49.

ONU, J.E., IHEMELANDU, E.C. and EZEASOR, D.N. (2002b): The effect of maternal alcohol consumption on the growth rate of body and testes in neonatal mice. Nig. J. Exp. Appl. Biol. 3(2): 159163.

ONU, J. E., EZEASOR, D. N; IHEMELANDU, E. C. AND NDONDO, N. (2004): Penile growth in foetal Alcohol Syndrome of mice. Phillipine J. Vet. Med. 4 .2: 100-104.

PIQUERAS-RENAU, J., MIRAGALL, P., GUERRI, C. and BAGUENA-CERVELLERA， R. (1987): Prenatal exposure to alcohol alters the golgi apparatus of newborn rat hepatocytes: A cytochemical study. The J. Histochem. Cytochem. 55(2): 221-228.

TAYLOR, A.N., BRANCH, B.J. and KOKKA, N. (1981): Neuroendocrine effectsof fetal alcohol syndrome. Endocrinological aspect of alcoholism. Prog.Biochem.Pharmacol. 18: 99-110.

TAYLOR, H. (1984): Minimal brain dysfunction in perspective: In Advanced Clinical Neuropsychology. TARTAR, H.E. and GOLDSTEIN, G. (eds). New York. Plenum Press.

ZETTERMAN, R.K. and SORREL, M.F. (1981): Immunologic aspects of alcoholic liver disease. Gastroenterol. 81: 616-624. 